Фармацевтичний менеджмент, маркетинг та логістика

Pharmaceutical management, marketing and logistics

Рекомендована д. фрармац. наук, проф. В. В. Трохимчуком

УдК 616.5+615.26-085:615.07+614.27]092.4

DOI

\title{
MARKETING ANALYSIS AND MONITORING OF PRICES FOR MEDICATIONS WITH CORTICOSTEROIDS OF SOFT DOSAGE FORM USED IN DERMATOLOGY
}

\author{
(C) B. V. Vons, M. B. Chubka, T. A. Hroshovyi \\ Ternopil State Medical University by I. Ya. Horbachevsky
}

\begin{abstract}
Summary: It was studied the assortment of soft medications with corticosteroids used in dermatology. It was found the correlation of domestic and foreign medications within each pharmacotherapeutic subgroup of medications. The price range was analyzed and the liquidity ratio for medications in this category was calculated too.
\end{abstract}

Key words: corticosteroids, soft dosage forms, price monitoring, market research.

Introduction. Every year the level of skin disease is growing rapidly. Today soft medications (SM) take the first place for the local treatment of dermatological diseases $[1,2]$. SM with corticosteroids (CS) are the most commonly used medications in dermatology. This group of medications (M) for over 50 years is used for treatment of dermatitis, eczema, erythema, psoriasis, for relieving symptoms of inflammation and itching of the skin [3]. The therapeutic effect of these medications is due to their anti-inflammatory, antihistamine and vasoconstrictor action.

However, the price is one of the constituent elements of pharmaceutical marketing and one of the most important factors determining the choice of buyers and demand for goods [4]. Taking into consideration, that CS belong to high-cost medications, the analysis of registered medications at the pharmaceutical market of Ukraine and price monitoring are actual issues.

The aim of research was to study the index of medication assortment with corticosteroids, summarize the results of price analysis, namely: the calculation of average retail prices of medications, liquidity ratios of prices, which were analyzed with the following justification of general trends.

Research methods. The object of the study was the information posted on the website «Regulatory and legislative documents of the Ministry of Health of Ukraine» [5] about registered SM in Ukraine and the method of analysis of used secondary marketing information. The electronic on-line directory «Compendium» [6] was used as an information source. The system-viewing method, graphic, documentary and marketing methods were used for the research.

Results and discussion. There has been 492 names registered, of which 226 medications are used in dermatology according to preliminary studies, for the date of January 1, 2015.

The largest number of registered medicines belongs to the group of medications with corticosteroids (D 07), 80 medications are used in dermatology. According to the order No. 235 «classifier dosage forms» [7] of MPH of Ukraine, all registered medications with CS were divided due to their dosage form into creams, ointments, gels, pastes, liniments (Fig. 1).

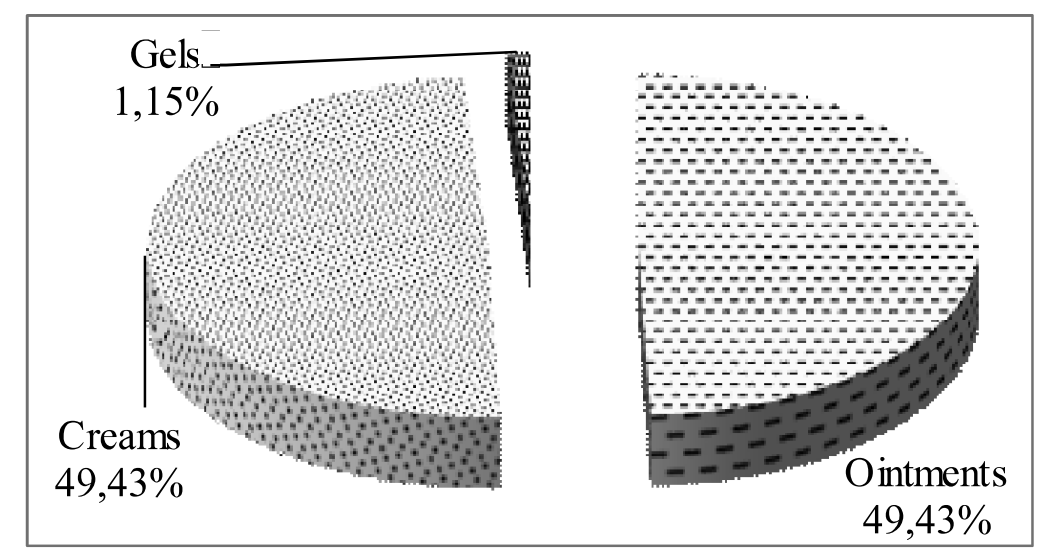

Fig. 1. The assortment of SM with corticosteroids considering the type of dosage form

ISSN 2312-0967. Фармацевтичний часопис. 2015. № 4 
Thus, in the ratio ointments and creams have 49.43 $\%$ of the assortment, gels only $1.15 \%$ and corticosteroid medications such as liniments and pastes are not represented on the pharmaceutical market of Ukraine.

The domestic market of SM with CS depends on import because soft dosage forms (SDF) of foreign manufacturing take $73.56 \%$ of assortment, while soft dosage forms (SDF) of domestic production have $26.44 \%$ of the market.

SM with CS are represented by 12 countries of the world at Ukrainian market, the leaders are: Poland $21.87 \%$, India - $14.06 \%$, Italy - $12.5 \%$, Germany $10.93 \%$, Belgium and Croatia - 9,37 \% each. Other countries, import of which is not higher than 5 medications, occupy $21.90 \%$ of the Ukrainian market of SDF.

In Ukraine, SM with corticosteroids are produced by 8 pharmaceutical enterprises of different ownership. Leading manufacturing positions are occupied by Pharmaceutical Company Zdoroviya, LLC - $26.08 \%$, Farmak, PJSC, Pharmaceutical company Darnytsiya, PJSC and Kievmedpreparat, PJSC have $17.39 \%$ each of pharmaceutical market. Other pharmaceutical companies that have production of soft dosage forms with CS no more than 3 medications occupy $21.75 \%$ of the market.

Price is one of the most important elements of the marketing complex because it determines the monetary price paid for a particular product [8].

Price features of SDF with CS presented at the domestic wholesale market from January 2015 to May 2015 were investigated during the research. In particular, dynamics of changes, average weighted wholesale price and liquidity ratios were studied. Wholesale prices presented on an electronic resource «Ezhenedelnyk apteky» [9] were used for the analysis.

We analyzed the pricing environment of SDF with CS and defined liquidity ratio, which has showed the balance between the maximum and minimum price of a particular medication at a current period at the appropriate market [4] for this category of medications of soft dosage form during January - May 2015 (Fig. 2).
$6.89 \%$ of medications of soft dosage forms with CS have liquidity ratio less than 0,15 , it may indicate that these medications are not demanded at the market, or a manufacturer specifically limits the number of mediators in a specific geographic region using the selective distribution and giving the exclusive right to sell its goods.

At $52.89 \%$ of medications liquidity ratio range between $0,15-0,5$ is permitted for standards and typical for sales of domestic medications, which is mainly performed as single, two, or zero level of marketing channel.

$40.22 \%$ of medications of soft dosage form with CS have liquidity ratio higher than 0,5 , it means that the price volatility is $50 \%$ and higher. When this ratio is higher than 1,0, it means that the range of prices of this medication is currently characterized by more than one hundred percent difference.

Also it was found the average arithmetic wholesale prices for this group of medications during the studied period. All SM with corticosteroids (group D 07 according to ATC classification) were analyzed due to the international non-patented name and divided into domestic and imported medications (Table 1)

Average price for 1 pack of medication of MDF with corticosteroids had a significant tendency to change a price during the period of study. The wholesale price of the medication with $\mathrm{CS}$ of domestic manufacturer varies from $\mathrm{UAH} 14.02$ per pack to 67.43 $\mathrm{UAH}$, while the price of imported medication is from 19.89 UAH to 267.35 UAH per one pack. It should be noted that the price of imported medications is higher in three times than the price of domestic counterparts. For example, we compared German medication Soderm and medications of domestic manufacturers such as Betazon (Zdorovya, LLC) and Mezoderm (Borshchagivskyy CPF, CJSC). They belong to the same group of ATC classification (D07AC01) and are produced as cream and contain the same amount of active pharmaceutical ingredient - betamethasone and relatively similar excipients composition, but prices differ

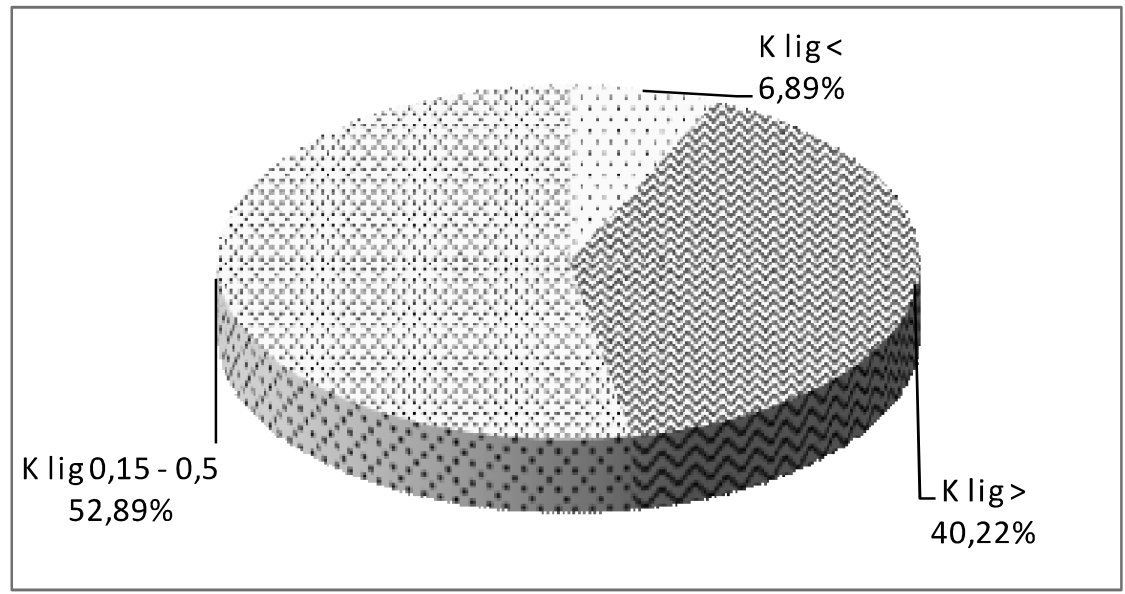

Fig. 2. The data value of liquidity ratios of SM with corticosteroids

ISSN 2312-0967. Pharmaceutical review. 2015. № 4 
Фармацевтичний менеджмент, маркетинг та логістика Pharmaceutical management, marketing and logistics

Table 1. The assortment and pricing policy of corticosteroids for using in dermatology D07 group

\begin{tabular}{|c|c|c|c|c|c|}
\hline ATC-code & $\begin{array}{l}\text { International non- } \\
\text { patented name (NN) }\end{array}$ & $\begin{array}{c}\text { Number of names } \\
\text { of domestic } \\
\text { medications }\end{array}$ & $\begin{array}{c}\text { Average } \\
\text { wholesale price, } \\
\text { UAH per one } \\
\text { pack }\end{array}$ & $\begin{array}{c}\text { Number of names } \\
\text { of imported } \\
\text { medications }\end{array}$ & $\begin{array}{c}\text { Average } \\
\text { wholesale } \\
\text { price, UAH per } \\
\text { one pack } \\
\end{array}$ \\
\hline D07AA02 & Hydrocortisone & - & - & 1 & 25,12 \\
\hline D07AA03 & Prednisolone & 1 & 18,04 & 1 & 19,89 \\
\hline D07AB02 & $\begin{array}{l}\text { Hydrocortisone } \\
\text { butyrate }\end{array}$ & - & - & 5 & 109,03 \\
\hline D07AB09 & Triamcinolone & 1 & 20,45 & 1 & 84,02 \\
\hline D07AB10 & Alklometazon & - & - & 2 & 81,30 \\
\hline D07AC01 & Betamethasone & 3 & 37,52 & 3 & 82,61 \\
\hline D07AC04 & $\begin{array}{l}\text { Fluocinolone } \\
\text { Acetonide }\end{array}$ & 2 & 14,02 & 3 & 48,66 \\
\hline D07AC13 & Mometasone & 2 & 53,80 & 7 & 164,53 \\
\hline D07AC14 & $\begin{array}{l}\text { Methylprednisolone } \\
\text { aceponate }\end{array}$ & 2 & 54,23 & 2 & 131,19 \\
\hline D07AC17 & Fluticasone & - & - & 2 & 84,21 \\
\hline D07AC18 & Prednicarbate & - & - & 2 & 87,25 \\
\hline D07AD01 & Clobetasol & 1 & 37,72 & 8 & 71,77 \\
\hline D07BB01 & $\begin{array}{l}\text { Flumethasone and } \\
\text { Antiseptics }\end{array}$ & - & - & 1 & 71,85 \\
\hline D07BB03 & $\begin{array}{l}\text { Triamcinolone and } \\
\text { Antiseptics }\end{array}$ & 1 & 41,70 & - & - \\
\hline D07BC01 & $\begin{array}{l}\text { Betamethasone and } \\
\text { Antiseptics }\end{array}$ & - & - & 1 & 267,35 \\
\hline D07CA01 & $\begin{array}{l}\text { Hydrocortisone and } \\
\text { Antibiotics }\end{array}$ & - & - & 5 & 83,17 \\
\hline D07CC01 & $\begin{array}{l}\text { Betamethasone and } \\
\text { Antibiotics }\end{array}$ & 3 & 67,43 & 10 & 134,40 \\
\hline D07CC04 & $\begin{array}{l}\text { Beclometasone and } \\
\text { Antibiotics }\end{array}$ & - & - & 1 & 127,60 \\
\hline D07CC05 & $\begin{array}{l}\text { Flumethasone and } \\
\text { Antibiotics }\end{array}$ & 1 & 38,03 & - & - \\
\hline D07XA02 & Prednisolone & 1 & 23,86 & 1 & 171,86 \\
\hline $\mathrm{D} 07 \times \mathrm{CO} 01$ & Betamethasone & 2 & 49,92 & 2 & 116,32 \\
\hline D07CC03 & Mometasone & 1 & 56,98 & 1 & 210,75 \\
\hline
\end{tabular}

significantly. So, during the analyzed period the average wholesale price of medication Soderm is 104.42 $\mathrm{UAH}$, Mezoderm - 40.97 UAH, Betazon - UAH 38.75 respectively.

Among the companies which offer at Ukrainian pharmaceutical market corticosteroids medications (D 07A), during the studied period the highest average prices are for certain medications of the subgroup D07AA - corticosteroids with low activity (group I) and D07AB - moderately active corticosteroids (group II), in particular: Lokoyid cream and Lokoyid Lipokrem ointment (manufactured in Italy) (Fig. 3).
During the researched period, for subgroup of corticosteroids D07AC - active corticosteroids (group III) and D 07AD - highly active corticosteroids (group IV) the highest average price are for the following medication: cream Tselestoderm -B of Belgian company Schering-Plough Labo N.B. and Momat cream of Indian company HlenmarkPharmacuticals LTD. These medications belong to the category of high-costed medication (Fig. 4).

The maximum price for the medication Momat cream was observed in February 2015 and Tselestoderm-B had high price in the period of January-March.

ISSN 2312-0967. Фармацевтичний часопис. 2015. № 4 
Фармацевтичний менеджмент, маркетинг та логістика Pharmaceutical management, marketing and logistics

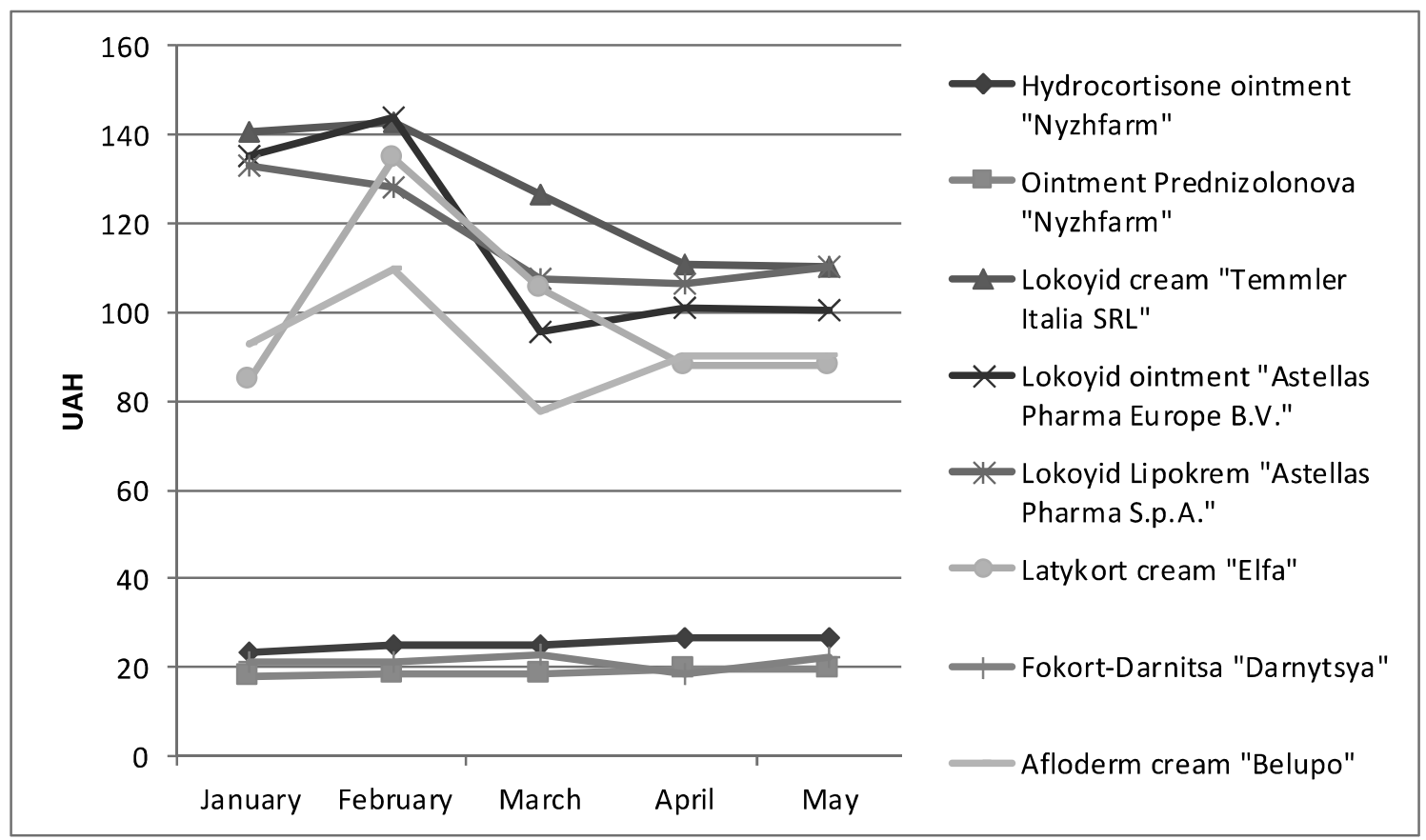

Fig. 3. Dynamics of change of average wholesale prices of medication for subgroup D07AA - corticosteroids with low activity (group I) and D07AB - moderately active corticosteroids (group II).

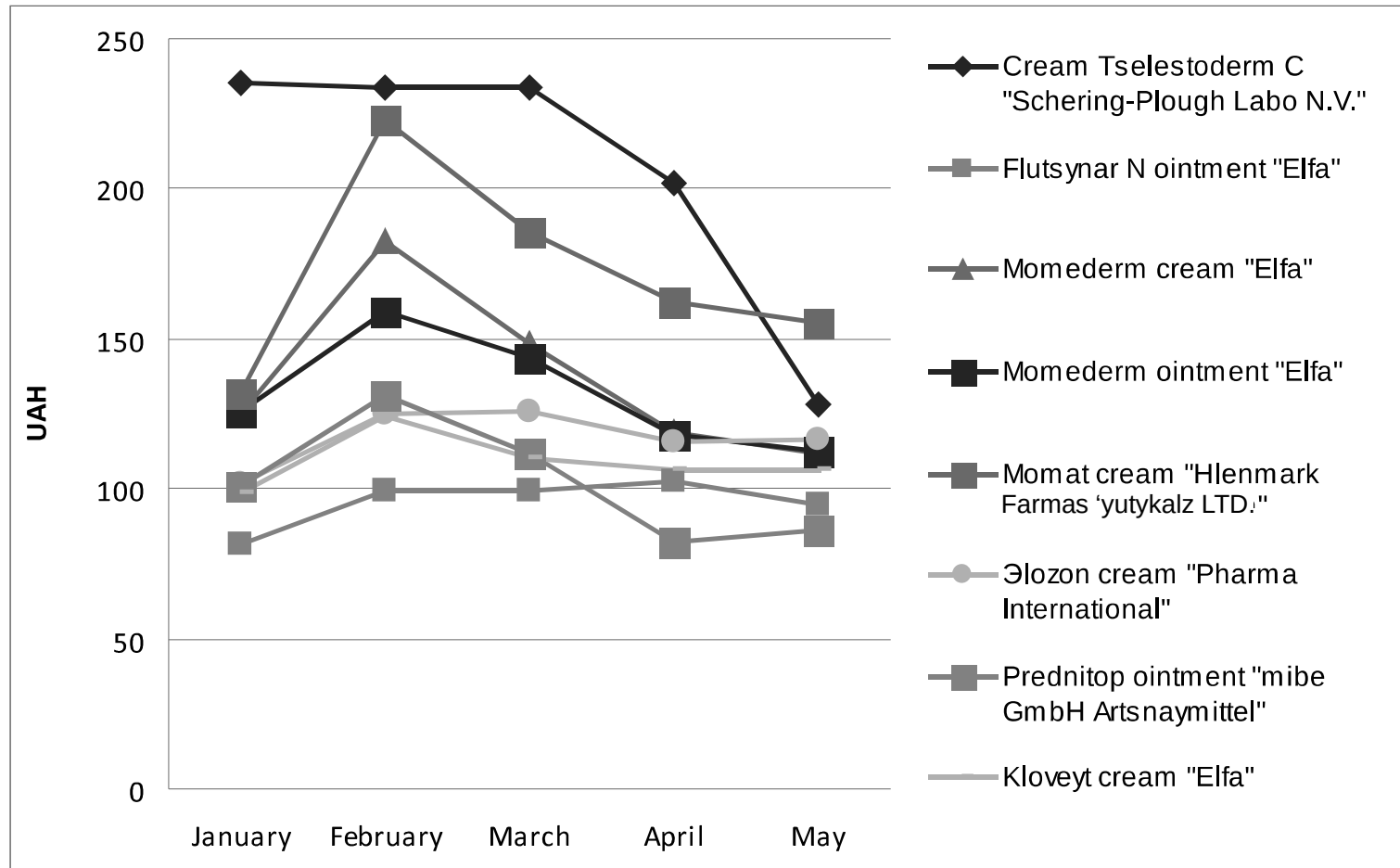

Fig. 4. Dynamics of change of average wholesale prices of medication for subgroup D07AC - active corticosteroids (group III) and also subgroup D07AD - highly active corticosteroids (group IV).

\section{Conclusions}

1. The domestic market of SM used in dermatology has been analyzed and it was found that for the date of January 1, 2015, 226 medications were registered in
Ukraine, of which $80 \mathrm{SM}$ with corticosteroids are produced in the form of ointments and creams.

2. It was determined that $73.56 \%$ of all SM with corticosteroids are of foreign manufacturers, the main importing

ISSN 2312-0967. Pharmaceutical review. 2015. № 4 
Фармацевтичний менеджмент, маркетинг та логістика Pharmaceutical management, marketing and logistics

countries are Poland - $21.87 \%$, India - $14.06 \%$, Italy $12.5 \%$, Germany - $10.93 \%$ Belgium and Croatia $9.37 \%$ each. The leading domestic manufacturers of SM with corticosteroids are Pharmaceutical Company Zdorovya, LLC; Farmak, JSC, Pharmaceutical company Darniysa, PJSC; and Kyivmedpreparat, JSC of Arteriuum Corporation.

3. The market pricing environment of SM for dermatological disease treatment was investigated at the pe- riod of January-May 2015. It was found that the average price per 1 pack of medication had a significant tendency to change over the researched period. SM with corticosteroids of import manufacture are more expensive than domestic counterparts.

4. Indicators of price liquidity for $62.89 \%$ of the studied medications are not higher than 0.5 , which is acceptable to consumers.

\title{
References
}

1. Vons B. V. Market analysis of semisolid dosage forms registered in Ukraine and research of excipients included to their formulas / B. V. Vons, M. B. Chubka, T. A. Groshovyi // Farmatsevtychnyy chasopys. - 2015. - № 1. - P. 55-61.

2. Analiz rynku zareyestrovanykh $v$ Ukrayini m'yakykh likars'kykh zasobiv, yaki vykorystovuyut'sya u dermatolohiyi / B. V. Vons, T. A. Hroshovyy, M. B. Chubka // Menedzhment ta marketynh u skladi suchasnoyi ekonomiky, nauky, osvity, praktyky: materialy III mizhnarodnoyi naukovo-praktychnoy Internet-konferentsiyi, (26-27 bereznya 2015 r., m. Kharkiv). - KH.: Vyd-vo NFaU, 2015. - S. 303-304.

3. Shmelkova K. S. Problema vyboru suchasnoho topichnoho hlyukokortykosteroyidy / K. S. Shmelkova, O. L. Brykov // Mystetstvo likuvannya. - 2008. - № 8. - S. 114-16.

4. Kosyachenko K. L. Naukovo-metodychni pidkhody do otsinky efektyvnosti systemy tsin na likarski zasoby / K. L. Kosyachenko, A. S. Nemchenko, O. V. Kovalenko // Visnyk farmatsiyi. - 2010. - № 3. - S. 51-54.

5. Normatyvno-dyrektyvni dokumenty MOZ Ukrayiny [Elektronnyy resurs] / Ministerstvo okhorony zdorovya Ukrayiny. - Rezhym dostupu do informatsiyi: http:// mozdocs.kiev.ual.

6. Dovidnyk «Kompendium». [Elektronnyy resurs]. Rezhym dostupu do informatsiyi: http://compendium.com. ual.

7. Nakaz Ministerstva okhorony zdorov'ya Ukrayiny vid 26.06.2002 roku № 235 «Pro zatverdzhennya Klasyfikatora likars'kykh form» [Elektronnyy resurs] / Ministerstvo okhorony zdorov"ya Ukrayiny. - Rezhym dostupu do informatsiyi: .http://mozdocs. kiev.ua/view.php?id=1113.

8. Myrzabekova M. YU. Mekhanyzm tsenoobrazovanyya v sovremennoy ékonomyke / M. YU. Myrzabeova // Ékonomyka y upravlenye v XXI veke: tendentsyy razvytyya. - 2013. - № 11. - S. 106-110.

9. Ezhenedel'nyk apteka. [Elektronnyy resurs]. - Rezhym dostupu do informatsiyi: http://pharmbase.com.ua/poisk.

\section{АНАЛІЗ РИНКУ ТА МОНІТОРИНГ ЦІН НА ЛІКАРСЬКІ ЗАСОБИ 3 КОРТИКОСТЕРОЇДАМИ М'ЯКОЇ ФОРМИ ВИПУСКУ, ЩО ВИКОРИСТОВУЮТЬСЯ В ДЕРМАТОЛОГІї}

\section{Б. В. Вонс, М. Б. Чубка, Т. А. Грошовий}

Тернопільський державний медичний університет імені І. Я. Горбачевського

Резюме: досліджено асортимент м'яких лікарських засобів 3 кортикостероїдами, які використовують у дерматології. Визначено співвідношення лікарських засобів вітчизняного та іноземного виробництва в межах кожної срармакотерапевтичної підгрупи лікарських препаратів. Проаналізовано ціновий діапазон, розраховано коефріцієнт ліквідності для препаратів даної категорії.

Ключові слова: кортикостероїди, м’які лікарські форми, моніторинг цін, маркетингові дослідження.

\section{АНАЛИЗ РЫНКА И МОНИТОРИНГ ЦЕН НА ЛЕКАРСТВЕННЫЕ СРЕДСТВА С КОРТИКОСТЕРОИДАМИ МЯГКОЙ ФОРМЫ ВЫПУСКА, ПРИМЕНЯЕМЫЕ В ДЕРМАТОЛОГИИ}

\author{
Б. В. Вонс, М. Б. Чубка, Т. А. Грошовый \\ Тернопольский государственный медицинский университет имени И. Я. Горбачевского
}

Резюме: исследовано ассортимент мягких лекарственных средств с кортикостероидами, которые используют в дерматологии. Определено соотношение лекарственных средств отечественного и иностранного производства в пределах каждой фрармакотерапевтической подгруппы лекарственных препаратов. Проанализировано ценовой диапазон, рассчитан коэсфрициент ликвидности для препаратов данной категории.

Ключевые слова: кортикостероиды, мягкие лекарственные формы, мониторинг цен, маркетинговые исследования.

Отримано 10.08.2015

ISSN 2312-0967. Фармацевтичний часопис. 2015. № 4 